\title{
Morbidity of juvenile onset inflammatory bowel disease: effects on education and employment in early adult life
}

\author{
A Ferguson, D M Sedgwick, J Drummond
}

\begin{abstract}
Seventy young adults (50 with Crohn's disease (CD) and 20 with ulcerative colitis (UC)) (from a geographically derived cohort of patients with juvenile onset inflammatory bowel disease were interviewed and examined at a mean of 14 (range 5.2-29.5) years after diagnosis. Details of education and employment were collected as part of a structured clinical interview. Although $57 \%$ had had periods of absence from school of two months or more, their school examination pass rates were similar to those of the healthy population. The achievements of CD patients were consistently better than those of the UC group. In 15 patients, relapses of inflammatory bowel disease had adversely affected examination performance or prevented them from sitting school examinations. Extra tuition in hospital had been provided for only four patients, and three others had had privately arranged tuition at home. Fifty per cent proceeded to full time higher education. At the time of review, seven patients were full time students, one was a university research fellow, 47 were in full time and three in part time employment, one was self employed, four were housewives, and only six were involuntarily unemployed. All four unemployed CD patients attributed this to inflammatory bowel disease, but other factors were relevant in the unemployed UC patients. Few had direct evidence of rejection by employers on health grounds, though some did not declare their illness to prospective employers.

(Gut 1994; 35: 665-668)
\end{abstract}

There is a high morbidity in children with inflammatory bowel disease, reflected by clinical parameters such as symptoms, number of hospital admissions, significant growth retardation, and frequent recourse to surgery. In contrast to the many studies of these clinical features, social morbidity in inflammatory bowel disease has been relatively neglected. Yet it is likely that the frequent and sometimes long absences from school or work associated with disease exacerbations will have profound, adverse effects on education and work performance.

By using the unique epidemiological facility provided by the Scottish Hospitals In-Patients Statistics (SHIPS) system, ' we derived a geographically based sample of patients who had developed juvenile onset inflammatory bowel disease between 1968 and 1983 (68 Crohn's disease (CD) and 37 ulcerative colitis (UC) and have previously reported details of their short term (seven years follow up) clinical progress. ${ }^{2-4}$ We have now undertaken a further review of this unique series of patients, at a mean follow up of 14 years (range $5 \cdot 2-29 \cdot 5$ years), ${ }^{5}$ to establish their health status in young adult life. We report here the details of their education and employment records, together with their views of the effects of inflammatory bowel disease on these aspects of their lives.

\section{Methods}

DERIVATION OF AN UP TO DATE COHORT OF PATIENTS FOR STUDY

Details of the methods used to derive the original sample of 105 patients have been published. ${ }^{2}$ The review of case records carried out in the mid1980s had shown that six patients had died and five had emigrated from Scotland during the 1970s. A further two UC patients (both in excellent health) had emigrated in 1982 and 1985. The remaining 92 patients were traced via hospital records, their parents, general practitioners, or from NHS regional records. With the agreement of the hospital consultant or family practitioner, the patients were contacted by letter and were invited to attend for clinical assessment. The general status of those who were unwilling to attend was evaluated by a telephone interview with either the patient or a parent.

The diagnosis in one patient had been revised from UC to $C D$, and two patients originally classified as CD had been redesignated as UC when histology of proctocolectomy specimens showed features of UC only. In a further patient with UC, it emerged at clinical interview that the age at onset of symptoms had been wrongly recorded in the hospital records, and the patient fell outwith the age criteria for the study.

There were thus 91 patients eligible for review, and 74 of these were seen and examined. There were four children aged $<18$ years (one $C D$, three UC), who were not considered further, 50 adults with $C D$ and 20 adults with UC. Telephone contact was made with the remaining $10 \mathrm{CD}$ and seven UC adults.

Full clinical and demographic details of the patients interviewed, and those traced but contacted only by telephone, are published elsewhere. ${ }^{5}$ For $\mathrm{CD}$, the two groups were very similar, whereas for UC, the patients who declined to attend for clinical examination were predominantly male with less extensive disease at presentation. Thus, the patients described below represent the full spectrum of juvenileonset $\mathrm{CD}$, but for juvenile onset UC, they are 
weighted in favour of the more severely affected cases from the original series.

For the 70 patients seen and examined, the age at onset of symptoms and age at clinical assessment are shown in Table I, together with the patients' description of their general state of health (which correlated well with other measures of disease such as the Crohn's disease activity index). The results presented below are based on the findings in these 70 adults.

The amount of time which had been spent as a hospital inpatient was similar for CD (mean 6.6 admissions, 102 days) and UC (mean 6.4 admissions, 93 days), and for men and women. ${ }^{5}$

\section{INFORMATION COLLECTED ON EDUCATION AND EMPLOYMENT}

Each patient had a structured interview conducted, relating to education and employment. This concerned details of examinations sat and passed, time lost from school or college due to inflammatory bowel disease; current and previous employment; and the patient's views on the effects (adverse or beneficial) of the bowel

TABLE I Age at onset of symptoms and at clinical assessment in 70 young adults with inflammatory bowel disease (mean $(S D)$ (range))

\begin{tabular}{lll}
\hline & $\begin{array}{l}\text { Crohn's } \\
\text { disease }\end{array}$ & $\begin{array}{l}\text { Ulcerative } \\
\text { colitis }\end{array}$ \\
\hline Age at onset $(y)$ & $12 \cdot 9(3 \cdot 3)$ & $12 \cdot 2(3 \cdot 6)$ \\
& $(2 \cdot 2-16 \cdot 9)$ & $(3 \cdot 6-16 \cdot 4)$ \\
Age at assessment $(y)$ & $26 \cdot 3(4 \cdot 5)$ & $27 \cdot 2(6 \cdot 1)$ \\
& $(18 \cdot 9-35 \cdot 6)$ & $(18 \cdot 2-38 \cdot 3)$ \\
Patient's view of recent general health: & \\
Well & 31 & 17 \\
Reasonable & 13 & 1 \\
Ill & 6 & 2 \\
\hline
\end{tabular}

TABLE II Number of passes achieved by inflammatory bowel disease patients in ordinary $(O)$ and higher $(H)$ grade examinations

\begin{tabular}{|c|c|c|c|c|}
\hline \multirow[b]{2}{*}{$\begin{array}{l}\text { No of } \\
\text { passes }\end{array}$} & \multicolumn{2}{|l|}{$O$ grade } & \multicolumn{2}{|l|}{$H$ grade } \\
\hline & $\begin{array}{l}\text { Crohn's } \\
\text { disease } \\
(n=50)\end{array}$ & $\begin{array}{l}\text { Ulcerative } \\
\text { colitis } \\
(n=20)\end{array}$ & $\begin{array}{l}\text { Crohn's } \\
\text { disease } \\
(n=50)\end{array}$ & $\begin{array}{l}\text { Ulcerative } \\
\text { colitis } \\
(n=20)\end{array}$ \\
\hline $\begin{array}{l}11 \\
10 \\
9 \\
8 \\
7 \\
6 \\
5 \\
4 \\
3 \\
2 \\
1 \\
\text { None } \\
\text { Not attempted } \\
\text { Currently taking } \\
\text { highers }\end{array}$ & $\begin{array}{r}1 \\
1 \\
3 \\
5 \\
6 \\
3 \\
8 \\
6 \\
2 \\
1 \\
3 \\
11\end{array}$ & $\begin{array}{l}1 \\
1 \\
7 \\
1 \\
3 \\
2 \\
\\
5\end{array}$ & $\begin{array}{l}1 \\
5 \\
4 \\
4 \\
4 \\
3 \\
1 \text { (failed) } \\
27\end{array}$ & $\begin{array}{r}17 \\
1\end{array}$ \\
\hline
\end{tabular}

TABLE III Percentages of school leavers, and of inflammatory bowel disease patients, holding a given qualification or better

\begin{tabular}{llll}
\hline & $\begin{array}{l}\text { All school } \\
\text { leavers } \\
(1981-85)\end{array}$ & $\begin{array}{l}\text { Crohn's } \\
\text { disease } \\
(n=50)\end{array}$ & $\begin{array}{l}\text { Ulcerative } \\
\text { colitis } \\
(n=20)\end{array}$ \\
\hline O grade: & & & \\
No passes & 36 & 22 & 25 \\
1 or more & 64 & 78 & 75 \\
3 or more & 49 & 70 & 65 \\
5 or more & 40 & 54 & 45 \\
Hrade: & 32 & 42 & 10 \\
1 or more & 21 & 28 & 10 \\
3 or more & 10.5 & 12 & 5 \\
5 or more & & & \\
\hline
\end{tabular}

$\mathrm{O}=$ ordinary grade $\mathrm{H}=$ higher grade . disease on education and employment. Details of pass rates in school examinations, for all Scottish school leavers, were obtained from the Scottish Education Department statistical bulletin. ${ }^{6}$

\section{Results}

\section{SCHOOL EXAMINATIONS}

During the period relevant to this study, Scottish children were eligible to attempt ordinary $(\mathrm{O})$ grade examinations, in the fourth or later years of Secondary education (around age 15-16 years), and higher $(\mathbf{H})$ grade examinations in the fifth and sixth years. Higher grade courses differ from English A levels in that the course work is for one year only and able children may study for up to six subjects simultaneously.

Passes in $\mathrm{O}$ and $\mathrm{H}$ grade exams in the $\mathrm{CD}$ and UC patients are detailed in Table II, and are compared with data for all Scottish school leavers in the period 1981-85 in Table III. Overall, results for the inflammatory bowel disease patients were similar to those for the general population. Achievements of the CD patients, however, were generally better than those of the UC patients. Twenty per cent of $C D$ patients obtained passes in eight or more subjects at $\mathrm{O}$ grade, whereas for UC, the maximum number of passes was seven. Twenty three (46\%) of the CD patients, but only three (15\%) of the UC patients attempted higher grade exams $\left(p<0.01, \chi^{2}\right.$ test). One 18 year old UC patient was preparing for these exams at the time of her review, and is represented by her $\mathrm{O}$ grade results in Table III. As discussed below, some of the examination successes in CD patients were achieved after leaving school.

EFFECTS OF INFLAMMATORY BOWEL DISEASE ON SCHOOL ATTENDANCE AND EXAMINATIONS

The more serious problems with education and examinations, encountered by the inflammatory bowel disease patients, are listed in Table IV.

Reported absences from school varied widely. Five CD and four UC patients reported little or no loss of time from school, but $28 \mathrm{CD}$ and $12 \mathrm{UC}$ patients had total absences of two months or more, mainly at the time of onset of their disease or for hospital admissions. Of the 70 young people interviewed, five did not take their O level examinations at the correct time and six others considered that their $\mathrm{O}$ level results had been adversely affected by their disorder. Absence from school was not always associated with poor examination results. One patient in this group had four months absence in his $\mathrm{O}$ level year but gained $11 \mathrm{O}$ levels and ultimately a BA degree.

Four patients had missed the opportunity to take higher level exams at school because of ill health, but three of these sat and passed the exams after attending evening classes or further education college later, when their disease was in remission. One man had lost more than two years of schooling, but after a period at a further education college to prepare for higher level examinations, he went on to gain a university degree. 
TABLE IV Problems with education and examinations attributed by the patients to inflammatory bowel disease

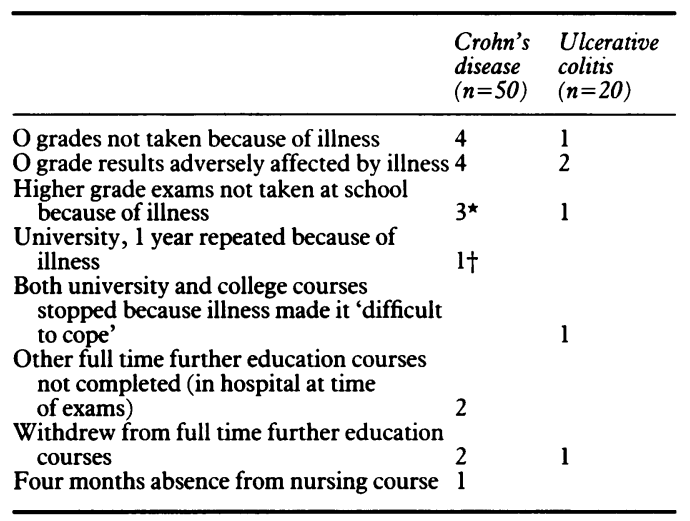

* These three CD patients passed higher exams later. See text. tOne $C D$ patient is currently at university and struggling to complete course, because of illness.

One man (currently a PhD student) felt that his illness had helped him to do well academically as he had had no energy for the diversions of social and sporting activities.

\section{EXTRA TUITION}

Extra tuition in hospital had been provided for only four patients (two CD, two UC). Two patients with $C D$ had had privately arranged tuition at home, and one borderline mentally retarded UC patient had also received private tuition at home.

\section{FURTHER EDUCATION}

Twenty five CD and 10 UC patients had attempted one or more full time further education courses (Table V) and seven of these were still students at the time of review. A further six $\mathrm{CD}$ and one UC patient had had day release or other part time training opportunities. Significant problems with this stage of education were fewer than during school years (Table IV). The percentages of inflammatory bowel disease patients who took up university courses $(14 \%$ $\mathrm{CD}, 5 \% \mathrm{UC}$ ) was similar to that for Scottish school leavers as a whole $(10 \cdot 1 \%) .^{7}$

\section{EMPLOYMENT STATUS}

The employment status of these 70 patients at the time of assessment is shown in Table VI. Of those who had completed their education, 30 of $43 \mathrm{CD}$ and 14 of 19 UC patients reported that
TABLE VI Employment status of inflammatory bowel disease patients at the time of clinical assessment, a mean of 14 years after onset of the disease

\begin{tabular}{|c|c|c|c|c|}
\hline & \multicolumn{2}{|c|}{$\begin{array}{l}\text { Crohn's disease } \\
(n=50)\end{array}$} & \multicolumn{2}{|c|}{$\begin{array}{l}\text { Ulcerative colitis } \\
(n=20)\end{array}$} \\
\hline & Male & Female & Male & Female \\
\hline $\begin{array}{l}\text { Eligible for work } \\
\text { (1 still at school) }\end{array}$ & 28 & 22 & 9 & 10 \\
\hline $\begin{array}{l}\text { Full time employment } \\
\text { Self employed }\end{array}$ & 21 & 11 & 8 & 7 \\
\hline $\begin{array}{l}\text { Part time employment } \\
\text { Housewife }\end{array}$ & & $\begin{array}{l}3 \\
2\end{array}$ & & 2 \\
\hline Unemployed & 1 & 3 & 1 & 1 \\
\hline Students & 4 & 3 & & \\
\hline $\begin{array}{l}\text { Post doctoral university } \\
\text { fellow }\end{array}$ & 1 & & & \\
\hline
\end{tabular}

TABLE VII Patients' views of the effects of inflammatory bowel disease on their education, employment, and career prospects

\begin{tabular}{lcc}
\hline & $\begin{array}{l}\text { Crohn's } \\
\text { disease } \\
(n=50)\end{array}$ & $\begin{array}{l}\text { Ulcerative } \\
\text { colitis } \\
(n=20)\end{array}$ \\
\hline Education: & 30 & 10 \\
Adversely affected & 2 & \\
Participation in sport restricted & 18 & 8 \\
$\begin{array}{l}\text { Education not affected } \\
\text { Not answered }\end{array}$ & 2 & \\
Employment and career prospects: & 24 & 5 \\
Adversely affected & 23 & 13 \\
Not affected & 3 & 1 \\
Not answered & & 1 \\
Still at school & & \\
\hline
\end{tabular}

they had had lost significant work time because of their illness.

Only six of the group were unemployed; all of the CD patients considered that inflammatory bowel disease was directly responsible for their unemployment, but this was not the view of the UC patients. Of the $C D$ patients, one woman (the only patient with intestinal failure in the series, who was on home total parenteral nutrition) had worked for only three weeks since leaving school and has been unemployed since because of her illness; another patient had been receiving invalidity benefit for five years, with occasional short term casual employment thereafter; one patient had recently been sacked because of illness; and one man, who had been recorded as 'physically and emotionally' immature in his mid-teens, had failed to find any employment. A further patient with no work skills had been unemployed for nine years before she acquired a recent job in the electronics industry. One patient reported that her applications for 11 jobs had been rejected because of her health record.

The unemployed UC patients had more complex disabilities. One was borderline

TABLE V Full time further education courses attempted by inflammatory bowel disease patients

\begin{tabular}{|c|c|c|c|c|c|c|c|c|}
\hline \multirow[b]{2}{*}{ Type of course } & \multicolumn{4}{|c|}{ Crohn's disease $(n=50)$} & \multicolumn{4}{|c|}{ Ulcerative colitis $(n=20)$} \\
\hline & Entered & Withdrew & Completed & $\begin{array}{l}\text { Still } \\
\text { attending }\end{array}$ & Entered & Withdrew & Completed & $\begin{array}{l}\text { Still } \\
\text { attending }\end{array}$ \\
\hline \multirow{6}{*}{$\begin{array}{l}\text { University degree } \\
\text { (proceeded to postgraduate } \\
\text { studentship) } \\
\text { Institute of technology } \\
\text { Degree course (nursing) } \\
\text { School of nursing } \\
\text { Radiography course } \\
\text { College courses (commerce, } \\
\text { trades, crafts) }\end{array}$} & 7 & & 4 & 3 & 1 & $1^{\star}$ & & \\
\hline & 2 & & 2 & & & & & \\
\hline & $\begin{array}{l}2 \\
1\end{array}$ & & $\begin{array}{l}1 \\
1\end{array}$ & 1 & & & & \\
\hline & 2 & & 1 & 1 & 1 & 1 & 1 & \\
\hline & & & & & & & 1 & \\
\hline & 13 & 6 & 6 & 1 & 8 & $3 \dagger$ & 5 & \\
\hline
\end{tabular}

* One UC patient withdrew from both a college course and from a university course because of illness.

† Two patients had to stop these courses when subsistence grants were withdrawn because of absence through illness. 
mentally retarded, and the other suffers from epilepsy in addition to UC. One of the housewives was visually handicapped because of cataracts associated with steroid treatment, and at the time of review, surgical treatment for this was being considered.

Few patients had any direct evidence that they had been rejected by employers on health grounds, although some reported that they now do not declare their illness to prospective employers. One employer had funded a recuperative holiday at the firm's holiday 'time-share' for a patient who had undergone major surgery.

\section{OVERALL VIEWS}

Overall, 40 patients considered that their education had been adversely affected by inflammatory bowel disease (Table VII) and two others commented that their participation in sports had been restricted; 29 patients felt that their illness had adversely affected their employment and career prospects.

\section{Discussion}

This study has confirmed our prediction that there is a significant social as well as medical morbidity in young adults with juvenile onset inflammatory bowel disease, reflected by absences from school, interference with examinations, and difficulties in pursuit of further education. Yet, it is remarkable that, at least as judged by school examination performance, the level of educational attainment of these young people is similar to that of the population as a whole; and for CD patients it is probably better. In a German study of adult CD patients, it was also noted that they had obtained higher qualifications in middle school (32.5\% success) than healthy and hospital control subjects $\left(21.7 \%\right.$ and $23 \cdot 3 \%$ successes respectively). ${ }^{8}$

It is unlikely, but possible, that the better academic performance of CD than UC patients is a result of selection bias. The original sample of 105 inflammatory bowel disease patients was geographically based, and thus fully representative of the diseases, CD and UC, as they occurred in Scottish children in the 1970s and early 1980s. For the present study we traced and contacted all who were still alive and resident in the UK. The 50 patients with $\mathrm{CD}$ seen and interviewed were similar in demographic and disease parameters to the group who were traced and contacted only by telephone; whereas for the UC patients, those who declined to attend were predominantly male with mild, distal UC. The UC patients who were interviewed had an equal sex ratio and represented the more severe and extensive form of the disease. On the other hand, although the time spent in hospital since diagnosis was similar for the UC and CD patients, the general health status of the $C D$ patient was poorer than that of the UC group, as reflected by the Crohn's disease activity index, prevalence of symptoms such as diarrhoea and abdominal pain, body mass index, and the patient's own appraisal of recent health status. $^{5}$

We have not broken down the examination results data in relation to sex but different sex ratios could not explain the better school examination results in $\mathrm{CD}$. In the population as a whole, girls achieve better results than boys, ${ }^{6}$ whereas there was a male excess in our CD series (28 men; 22 women). Clearly further studies are warranted to establish whether there is indeed a true difference in academic attainments when the two main forms of inflammatory bowel disease are compared, and whether the difference is present before the symptoms of inflammatory bowel disease develop. If the high academic achievements of CD patients are confirmed in a further cohort, there are many possible explanations - social class, intelligence, personality traits, nutritional factors, and family support.

This survey was conducted in 1989-90, when unemployment in the UK was lower than at present. Nevertheless, the rate of involuntary unemployment, at only six of 70 young adults, is remarkably low, and similar to the low rates in adult inflammatory bowel disease patients reported from Birmingham ( $5 \%$ unemployed) ${ }^{9}$ and Copenhagen ( $6 \%$ unemployed $)^{10}$ in the mid1980s. Clearly, although more than half of the young people interviewed considered that the range of career opportunities open to them had been restricted by the diagnosis of IBD, and although many had had significant loss of working time because of disease relapses, most were successful in gaining and retaining a satisfactory job.

Although the work performance of patients with inflammatory bowel disease can be affected by symptoms such as tiredness, malaise, diarrhoea, incontinence, and abdominal pain, the experience of adult patients has been that colleagues and employers are usually supportive, ${ }^{910}$ and this was also the case in the present study. Overt discrimination on the grounds of poor health is relatively unusual, even for those already suffering from inflammatory bowel disease when they enter adult life.

We are most grateful to the clinicians who allowed us to examine their patients and to medical records officers in hospitals throughout Scotland. We acknowledge the help and advice of Dr J Clarke and his staff in the Common Services Agency. This work is and his staff in the Common Services Agency. This work is Association), and by donations to the Edinburgh Intestinal Association), and by donations
Immunology Research Fund.

1 Barton JR, Gillon S, Ferguson A. Incidence of inflammatory bowel disease in Scottish children between 1968 and 1983; marginal fall in ulcerative colitis, threefold rise in Crohn's disease. Gut 1989; 30: 618-22.

2 Barton JR, Ferguson A. Clinical features, morbidity and mortality of Scottish children with inflammatory bowel disease. $Q \mathcal{F}$ Med 1990; 75: 423-39.

3 Sedgwick DM, Barton JR, Hamer-Hodges DW, Nixon SJ, Ferguson A. Population based study of surgery in juvenile onset Crohn's disease. Br F Surg 1991; 78: 171-5.

4 Sedgwick DM, Barton JR, Hamer-Hodges DW, Nixon SJ, Ferguson A. Population based study of surgery in juvenile onset ulcerative colitis. $B r \mathcal{F}$ Surg 1991; 78: 176-8.

5 Ferguson A, Sedgwick DM. Morbidity of juvenile-onset inflammatory bowel disease: Health status in early adult life. School leavers qualifications 1988-89. The Scottish Office Statistical Bulletin, Education Series. May 1991. Edinburgh: Statistical Bulletin, Education Series. May 1991. Edinb
Government Statistical Service, 1991. Edn/E2/1991/4.

Scottish higher education statistics. The Scottish Office Statistical Bulletin, Education Series. August 1991. Edinburgh: cal Bulletin, Education Series. August 1991. Edinbur

8 Balzer K, Forster S, Goebell H, Seifert V, Kocker I. Demographische und soziale Charakteristik von Patienten mit Morbus Crohn in einer Grosstadtregion. Eine studie mit Nachbarschafts-und Krankenhauskontrollen. Z Gastroenterol 1985; 23: 347-54.

9 Wyke RJ, Edwards FC, Allan RN. Employment problems and prospects for patients with inflammatory bowel disease. Gut 1988; 29: 1229-35.

10 Sorensen VZ, Olsen BG, Binder V. Life prospects and quality of life in patients with Crohn's disease. Gut 1987; 28: 382-5. 